佐藤 平 [日本大学工学部建築学科 教授. 工博] 65 歳以上の高歯者向け住宅を改善する場合は, 平成 5 年 6 月付け 厚生省老人福祉局より, 各都道府県等の主幹部（局）長宛，住宅改 良「リフォーム」へルパーの運営方法に関する通知が出ております。

しかし本論文は工務店側から見た高㓻者住宅改善の実態に関する 調査報告一福井県におけるケーススタディーでありながら，上記通 知と今回の住宅改善の関連については全く触れておておりません。 せめて工務店が上記通知を知っていたのかどうか, 更にその改善結 果の評洒について利用者（施主）にとって良かったのか，亜かった のか等について記されておりません。

出来れば上記内容特に工務店の改良結果について，施主がどの様 に評価しているか等についても報告されたほうが良かったと思いま す。
水野弘之 [京都府立大学人間環境学部環境デザイン学科 教授・工博] 個々の内容には不十分な点はあるが，次のような点は高く評価で きる。(1)施工関係者（工務占側）の視点で研究した点（従来の研究 成果は設計関係者の視点のものが多い)。(2)福祉・保健・医療・建築 (設計と施工) などの連携の中で施工関係者の主体性の発揮の重要性 を論証した点（「5部まとめ」の項の最後の6 行参照)。

(3)上記の(2)は，わが国の近年の建築の歴史上極めて重要であると 考えられる点。その理由の第 1 は, 一般の住宅改造では, 設計者と施 エ者の間には上下関係が生じやすいが，この上下関係を福祉・保健・ 医療・建築が連携した住宅ケアのための住居改善の支援の取り組み (*1)に持ち込むことは, 住居改善の成功の妨げになるからである。 理由の第 2 は,上記の上下関係を打破することは, 設計者と施工者と いう建築関係者同士（建築分野の枠内）では解決困難な問題であり， 上記 (*1)のよjな取組の中でこそ，解決しうると考えられるから である。

\title{
STUDY ON THE LIVING SPACE PLANNING VIEWING FROM COMMUNITY ACTIVITIES BY COLLECTIVE LIVING AND LEISURE ACTIVITY PART 5-“Aruju" a community cooperative rental residence Part 2- UmekazU KAWAGISHI, Hiroyuki SUDO 341
}

服部岑生 [千葉大学工学部デザイン工学科 教授・工博] 非常に先進的なコーポラティブ住宅「あるじゅ」は，賃貸型コー ポ，地主と共住するコミュニティーなど様々な話題があり，興味深 く読んだ。そのコミュニティー活動や居住者の意見が調查されてい て，「あるじゅ」の実態が浮かび上がってくる報告になっている。連 続するバルコニーやコモンスペースとしての外部空間の意味が，参 加型観察によってjまく捉えられている。また賃貸住宅であるので 定住性や帰属意識のないと考之られる居住者が州属性などの正反対 の意識を持つことが示されている。これは建築の特徵や地主と居住 者のコミュニケーションによってもたらされているようだ。筆者ら は, 多くの新しい住宅計画について調查報告を行っており, 貴重な 研究蓄積を持っている点は多いに敬意を表する次第である。少々の 疑問だが，住宅調査では居住者などの内部者の見解は，どのような ものであれ肯定的になるといわれる。この報告にそのような感じが ある気がする。
延藤安弘 [まちの縁側育くみ隊 代表理事・工博 $]$ 現代のレディメード型の集住はハード・ソフト両面において，外 在的・拘束的になる傾向をいっそう強めている。しかし，ユーザー 参加によるコーポラティブ住宅では, 内在的・自律的な相互関係・ コミュニケーションの多様な世界が生成する。本研究は, 䛒貸型の コーポラティブ住宅の際立った典型としての「あるじゅ」の住まい 万の状況にそのことが具現化していることを検証している。集住が 不可避的に発生させるトラブルを外在的・拘束的に㧕止するのでは なく，状況に応じてメンバー間で，時には，オーナー（地主）の参 加もえて開かれた討論・对話を重ね，トラブルを正のエネルギーに 変換させる過程を適確にとらえている。集住コミュニティは単一価 值の拘束的なものではなく,ダイナミックな correlation・関係づくり によって，多元的価值を状況の中で相互に発見して共有していくも のである。自己も他者も，人間も空間も発達していく相互歓待的な 関係を創成することが，コミュニティデザインであると示唆されて いる。
大野隆司 [東京工芸大学工学部建築学科 教授・工博] 開発研究は技術報告集の趣旨に適ったテーマの一つであるが，こ との性格上, 詳しい内容は省略される場合が多い。本報告は詳細に わたって丁㔤に紹介されている。気になった点を以下にあげる。

1) 動産と不動産 (インフィルとスケルトン) との境界を床仕上げ面 としているが, 利用者によってインフィルが変更されるケースを 考えると，やはり床スラブ面がよいのでは？

2）床仕上げ面を境界々設定した以上，（床スラブとの結合関係を弱 めて）配管類を床システムから吊る必然性があるか？

3）配管類を設置する共同溝用の床システムは,そうでない一般の床 システムとは別仕様でもよいのでは？

4）ありきたりの指摘であるが, 圧送ポンプの不具合時への対応は？
岩下繁昭 [ものつくり大学建設技能工芸学科 教授・工博 $]$ 設備系のインフィルの設置・維持・交換・回収を容易にするため に，床システムをまさに共通なプラットホームにするといった開発 研究の報告である。類似の開発試行例はいくつか見られるが，床子 ところ寸法を最小限に抑えることと, 床システムと設備系インフィ ルのインターフェースを，サヤ管のスリーブのみとしたことが大き な特徵となっている。こうした開発ではとかく床システム側に設備 配管の接続機能も持たせがちであるが，ここでは床システムに取り 付けられたスリーブ部品を介して，サヤ管へッダー万式で配管し， 配管接続はあくまでもインフィル側で行うようにしている。これに よりインターフェースのルールが単純なものになり，共通なプラッ

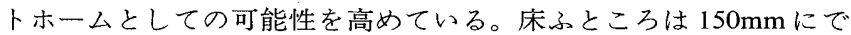
きることが試行実験により確認されたが，さらにこのスペースを活 用し，バリアフリー対応の浴公ユニットとの両立性も確保できるよ うにすることが望まれる。 